\title{
Role and importance of companies in shaping and functioning of the innovation system
}

\author{
Zijada Rahimic ${ }^{*}$
}

\begin{abstract}
By continuously strengthening research and development (R\&D) activities and innovative capabilities, companies are achieving long-term sustainable competitive advantages in today's increasingly complex and uncertain markets. At the same time, by creating new knowledge, innovative application of existing knowledge and technologies, and facilitating their transfer, they contribute to building a knowledge economy and the country's competitiveness. One of the pillars of the knowledge economy is an effective innovation system, in which companies have a special place and role. The aim of this paper is to present and analyse the contribution of companies to the efficient functioning of innovation systems, to examine the relationship and impact of innovation and R\&D expenditures on global competitiveness. The Global Innovation Index (GII) and the Global Competitiveness Index (GCI), in which innovation and sophistication represent one of the three categories of competitiveness, were used as a methodological framework for analysing the effects of innovation capabilities. The focus of the analysis was the relationship between innovation inputs and innovation outputs, as well as the relationship between the GII and GCI of Bosnia and Herzegovina, the countries of the Western Balkans and the group of selected countries of the European Union (EU). The research results show that there is a statistically significant relationship between innovation inputs and outputs. There are obvious differences in the strength of the link between the variables of innovation and competitiveness for the countries of the Western Balkans and for selected EU member states. It was also found that R\&D expenditures significantly affect the value of the competitiveness index.
\end{abstract}

Key words: innovation system, knowledge economy, research and development, Global Innovation Index, Global Competitiveness Index

\section{Introduction}

In today's dynamic, uncertain environment characterized by globalization, extremely fast development of information and communication technologies, and the increasingly rapid obsolescence of knowledge, innovation and knowledge are especially important for building and maintaining a competitive position. In the modern economy, knowledge and innovation are key factors

\footnotetext{
* Prof Dr, Faculty of Economics, University of Sarajevo.

E-mail: zijada.rahimic@efsa.unsa.ba
} 
in the long-term sustainable survival and development of enterprises. ${ }^{1}$ The generation and use of knowledge plays a key role in the creation of national wealth in knowledge-based economies, which represent the modern paradigm of competitiveness of national economies. In that sense, the purpose of this paper is to point out the importance of innovative abilities and R\&D activities of companies for achieving their competitive advantages, for building and functioning of innovation systems and strengthening the competitiveness of the national economy. The subject of research are the concepts of innovation systems, and ways of measuring innovation performance and competitiveness. The aim of the paper is to present and analyse the contribution of companies to the functioning of innovation systems, to examine the relationship between innovation inputs and outputs, innovation and global competitiveness, as well as the strength of the impact of $R \& D$ expenditures on economic competitiveness.

Following the defined subject and set research goals, the paper is structured so that after the Introduction, the characteristics and importance of innovations and innovation systems are presented as one of the pillars of the knowledge-based economy in achieving competitive advantages. Special attention in this, the second part of the paper, is focused on the role of companies in the functioning of innovation systems. Then, various indices are listed, which aim to showcase and compare the results of innovation and global competitiveness of an economy with a focus on the presentation of the Global Innovation Index (GII) and the Global Competitiveness Index (GCI). Using these indices, an empirical research was conducted and the results of the analysis for $\mathrm{BiH}$, the countries of the Western Balkans and selected EU countries are presented. Finally, the conclusion presents the basic findings based on the results of theoretical and empirical research, and emphasizes the importance of companies for the effective and efficient functioning of innovation systems.

\section{Innovation system as one of the pillars of knowledge economy}

Constant changes, as a key characteristic of today's environment, are reflected, among other things, in the transition of classical industry to the technological era, ie in the fact that industries based on natural resources have been replaced by the so-called brainpower industries. The most developed

\footnotetext{
${ }^{1}$ Jovičić J. \& Petković S. (2016). Inovacije kao faktor konkurentnosti privrede s osvrtom na Bosnu i Hercegovinu, Obrazovanje za preduzetništvo, 6(1), 2016, p. 102.
} 
countries of today have achieved their success precisely by switching from a capital-intensive to knowledge-intensive economy. ${ }^{2}$ The generation, dissemination and effective use of knowledge play a key role in the creation of national wealth in these economies. Thus, the knowledge-based economy became the dominant economy of the twenty-first century.

The pillars of the knowledge-based economy include: human resources, modern and adequate information infrastructure, an effective innovation system and an institutional regime. The innovation system in a broader sense represents a functional unit of all public and private entities and institutions that directly participate in the creation of new knowledge through fundamental, applied and development research, innovative application of existing knowledge and technologies and facilitating their transfer within the country and in international exchange. ${ }^{3}$ In the context of the knowledge economy, it is important to point out the existence of partial coincidence and functional complementarity between the system of science on the one hand and the narrowly implied innovation system on the other, so that these terms are also used as synonyms. ${ }^{4}$

Having in mind the subject of research, the following segments will explain in detail the characteristics and importance of innovations and innovation systems in building the competitiveness of an economy, as well as the role of companies in the functioning of an innovation system. The most important indicators of innovativeness and competitiveness of an economy will also be presented.

\subsection{Importance of innovations and innovation systems in achieving competitiveness of an economy}

Innovation and innovation systems are becoming increasingly interesting to policy makers as means to achieving economic and social goals. Innovation is at the heart of the European Union's strategy because it provides "the best means of successfully addressing major societal challenges" (European

\footnotetext{
${ }^{2}$ Rahimić Z. \& Kožo A. (2009). Building and Development of the Knowledge Based Economy in Bosnia and Herzegovina. Journal of Interdisciplinary Management Research, Vol. V, January 2009, p. 112.

${ }^{3}$ Trifković M. (2020). Harmonizacija sistema nauke u Bosni i Hercegovini, Academy of Sciences and Arts of Bosnia and Herzegovina, Centre for Systemic Research, volume 5/1, special editions, Sarajevo, p. 34.

${ }^{4}$ Trifković M.(2020), p. 40.
} 
Commission, 2010). ${ }^{5}$ It has also recently been pointed out that research, innovation and education are crucial for Europe in the transition to climate neutrality and digital leadership. European industry, economy and society are changing at the speed of light, representing a unique opportunity to transform the EU into a fair and prosperous society, with a modern, resource-efficient and competitive economy that works for the people. ${ }^{6}$

The term innovation is often connected to technological changes, which include a new or innovative way of working or producing existing products or producing completely new products. However, all changes and all improvements within a company, but also in other spheres of life, can be covered under the concept of innovation.

$\mathrm{R} \& \mathrm{D}$ based knowledge is considered to be the most reliable source of innovation. However, other ways of acquiring and accumulating knowledge, such as "learning by doing" and "learning by using", are also extremely important. The perspective of practice conceptualizes the innovations located in the daily activities of organizing, learning and working. People create new knowledge as they work to solve problems they face in practice. In other words, knowledge, work and innovation are intertwined. In the knowledge economy, the creation of a knowledge base depends on the synergies achieved between the three main actors in an economy: the academia, the business community and the government.

Innovation is becoming an increasingly important factor in the fight to preserve and improve the competitive position of companies in the domestic and international market. ${ }^{7}$ In the global economic context, innovation has become a fundamental and decisive pillar of a country's development and its potential success. More precisely, innovation is an instrument of country's economic security and a factor in improving international competitiveness. ${ }^{8}$ The positive correlation between innovation and economic development has

\footnotetext{
${ }^{5}$ Schrempf B., Kaplan D. \& Schroeder D. (2013). National, Regional, and Sectoral Systems of Innovation-An overview. Report for FP7 Project" Progress". European Comission, http://ec.europa.eu/europe2020/index_en.htm, p.3.

${ }^{6}$ Science, Research and Innovation Performance of the EU 2020, A fair, green and digital Europe, European Commission, https:/ec.europa.eu/info/publications/science-research-andinnovation-performance-eu-2020_en

${ }^{7}$ Rahimić Z. (2006). Izgradnja konkurentskih prednosti preduzeća kroz njegova strateška opredjeljenja, Faculty of Economics Sarajevo, p. 275.

${ }^{8}$ Chuvakhina L.G., Terskaya G.A. \& Buevich S.Y.(2018). Innovations as a factor of state's improved performance in the World Economic System, Revista Espacios, Vol. 39 (\# 04) Year 2018.
} 
been confirmed in numerous empirical and theoretical studies, ${ }^{9}$ and it has been pointed out that increased innovation capabilities can lead to significant industrial development and the development of society in general. ${ }^{10}$

Increased awareness of the importance of innovation for economic growth has resulted in the development of the concept of a national innovation system (NIS). Special credit for the development of this concept is attributed to the British economist Christopher Freeman, who defines the national innovation system as a network of private and public sector institutions that initiate, import, modify and disseminate innovation through mutual interactions. ${ }^{11}$ NIS can be viewed as a socio-economic system in which various actors communicate, such as companies, research and academic organizations, public administration, professional intermediaries and other formal and informal institutions. NIS uses all available resources in the country, such as human, financial, infrastructural and institutional resources. NIS can also be considered an intangible asset ${ }^{12}$ that contributes to a country's economic growth, value creation and well-being.

The concept of national innovation systems is based on the assumption that the economic growth of a country, as a result of technological progress, does not depend so much on the size of $R \& D$ resources, but on the way of organizing and managing these resources at the national level. This attitude is especially important for small countries and developing countries, which, as a rule, do not have significant innovation capacity. ${ }^{13}$ Therefore, the national innovation system should be thoroughly examined in the context of developing countries, ${ }^{14}$ taking into account the capacity of knowledge production as well as the absorption capacity of end users, and the role of innovation policies.

\footnotetext{
${ }^{9}$ Kaynak S., Altuntas S. \& Dereli T. (2017). Comparing the innovation performance of EU candidate countries: an entropy-based TOPSIS approach, Economic Research-Ekonomska Istraživanja, 30:1, pp. 31-54.

10 Yongabo P. \& Göransson B. (2020). Constructing the national innovation system in Rwanda: efforts and challenges, Innovation and Development.

11 Freeman, C. (1995). The "National System of Innovation" in historical perspective. Cambridge Journal of Economics, 19 (1) 5-24., taken from Cvetanovic D. (2020)

12 Gogodze J. (2016). Mechanisms and Functions within a National Innovation System, Journal of Technology Management\&Innovation,Universidad Alberto Hurtado, Facultad de Economía y Negocios. Volume 11, Issue 4, pp. 12-21.

${ }^{13}$ Cvetanovic D., Cvetanović S. \& Bogić D. (2020). Rastući značaj koncepta regionalnih inovacionih sistema za ekonomski i društveni razvoj, https://konferencija.komorapirot.com/44. RASTUCI $\% 20 Z N A C A J \% 20 K O N C E P T A \% 20 R E G I O N A L N I H \% 20 I N O V A C I O N I H \% 20$ SISTEMA\%20ZA\%20EKONOMSKI\%20I\%20DRUSTVENI\%20RAZVOJ.pdf

${ }^{14}$ Yongabo P. \& Göransson B (2020). Constructing the national innovation system in Rwanda: efforts and challenges, Innovation and Development, DOI:10.1080/2157930X.2020.1846886
} 
The concept of efficiency of a national innovation system is directly related to the concept of productivity. An innovation system is considered to be efficient when it generates more innovation results with the same amount of innovation inputs, ie when fewer inputs are needed to create the same volume of innovation. ${ }^{15}$

The Oslo Manual (OECD, 2005) identifies four factors that affect the efficiency of the innovation process: framework conditions, science and technology institutions, transmission mechanisms, and company-specific innovative drives. The general framework conditions shape the activities of enterprises and their ability to perform innovative activities. The efficiency of science and technology institutions drives the accumulation of knowledge. Transmission mechanisms improve the flow of information and skills between stakeholders and ensure that innovative ideas reach the market. Finally, companies themselves need to identify and use the potential for innovation to strengthen the innovation process. The presented factors correspond to certain areas of intervention policies. The government is expected to create measures to address potential barriers and set priorities ${ }^{16}$ Generally, the state is considered to be the most influential factor in most national innovation systems, as it finances most of the fundamental research and development activities in the country. ${ }^{17}$

In addition to these factors, historical heritage can have a profound impact on the shape of national innovation systems. ${ }^{18}$ Indeed, historical events and social norms in each country have had a major impact on the form of institutions, the articulation of priorities, and the results of innovation. However, thanks to the trend of continuous learning, the differences between national innovation systems observed in previous decades are less obvious today. ${ }^{19}$ For

15 Jankowska B., Matysek-Jędrych A. \& Mroczek-Dąbrowska K. (2017). Efficiency of national innovation systems: Poland and Bulgaria in the context of the Global Innovation Index, Comparative Economic Research, De Gruyter, Warsaw, Vol. 20, issue 3, pp. 77-94.

${ }^{16}$ OECD (2013). Triple Helix partnerstva za inovacije u Bosni i Hercegovini, Razvoj privatnog sektora - Priručnik za politike, Sarajevo, p. 17. and OECD (2005), Oslo Manual: Guidelines for collecting and interpreting innovation data, issue 3, OECD, Paris.

${ }^{17}$ Melaas A. \& Zhang F. (2016). National Innovation Systems in the United States and China: A Brief Review of the Literature, The Center for International Environment\&Resource Policy, Tufs University.

18 Radošević S. (2002). Regional innovation systems in Central and Eastern Europe: Determinants, organizers and alignments. J. Technol. Transf. 2002, 27, 87-96. Taken from: Mosurović Ružičić M., Miletić M. \& Dobrota, M. (2021). Does a National Innovation System Encourage Sustainability? Lessons from the Construction Industry in Serbia. Sustainability 2021, 13, 3591, p. 5.

${ }^{19}$ Fatma A. (2018). Overview of the Japanese Innovation Systems vs. the American Innovation System. J Glob Econ 6: 312. 
example, Japan's innovation system is based on "alternative energy technology" or energy efficiency, and the dominant concept in the United States is "innovation ecosystem."

Innovation systems can operate at national, regional or international level. Regardless of the level, the observation dimension of the innovation system emphasizes the importance of producing and using new knowledge in creating value. ${ }^{20}$ In the process of production and dissemination of knowledge, the engagement of all actors, trust and loyalty among the actors and a supportive environment are considered particularly important. ${ }^{21}$

\subsection{The role of companies in the functioning of an innovation system}

Initial research into national innovation systems, in the early 1990s, aimed to measure companies' innovation performance through the development of new products, as well as their ability to absorb innovative technologies. ${ }^{22}$ It was during this period, at the end of the 20th century, that the company's success was based on innovative ability due to the growing uncertainty and turbulence of changes in the environment, unlike in the 60's when the company's goal was to increase production, or 70's when focus was on reducing production costs, and the 80's when companies aimed to achieve high quality. The innovative capabilities of companies contribute to achieving and maintaining their own competitive advantages, as well as the country's competitiveness. Starting from the fact that market dynamics and market uncertainty will increase in the future, it can be said that companies should strive to strengthen their R\&D activity, ie to strengthen innovation capabilities. The R\&D activity of a company depends not only on the capabilities of the company but also on factors from the external environment. Among them, the attitude of the government (state) towards scientific research, the strong connection between scientific research institutions (universities and institutes) with economic entities, the speed of technological transfer and the rate of obsolescence of technologies, which is related to the type of business. Therefore, recent research has focused on the specific roles of other actors within the innovation

\footnotetext{
${ }^{20}$ Schrempf B., Kaplan D. \& Schroeder D. (2013). National, Regional, and Sectoral Systems of Innovation-An overview. Report for FP7 Project" Progress". European Comission.

${ }^{21}$ Chaminade, C. \& Lundvall B. (2019). Science, Technology, and Innovation Policy:Old Patterns and New Challenges. Oxford: Oxford University Press.

${ }^{22}$ Melaas A. \& Zhang F. (2016). National Innovation Systems in the United States and China: A Brief Review of the Literature, The Center for International Environment\&Resource Policy, Tufs University.
} 
system, such as the role of government in creating incentives and the role of universities in conducting research. ${ }^{23}$ In this sense, it is interesting to note that the EU supports industry research and innovation, as two thirds of investments in R\&D and private sector development generates $80 \%$ of EU exports. ${ }^{24}$

The Conceptual Model for Analyzing Industry-Science Relations ${ }^{25}$ is considered a tool for raising the competitiveness and technological performance of companies using the knowledge available in public research. The goal of promoting the relationship between industry and science is to ensure that public investment in higher education spills over to businesses and makes that investment economically productive. The model of the relationship between industry and science is considered to be the result of activities of actors in the "knowledge market", which is characterized by high asymmetry of information between participants and low market transparency, high transaction costs of knowledge exchange, restrictions on financing production and knowledge exchange due to financial markets reluctant to risk and with short-term orientations. The performance of the industry-science relationship is influenced first by the characteristics of the main stakeholders (companies and public scientific institutions) through supply and demand in the national knowledge market, secondly by framework conditions such as infrastructure, legislation and regulations and institutional settings, and thirdly by the intensity of mutual communication between industry and science.

Innovation can be encouraged by applying the Triple Helix model, i.e. cooperation between the academic and business community and the local government. ${ }^{26}$ Coordinated activities of all three stakeholders and efficient communication enable the achievement of synergetic effects and the creation of higher value. ${ }^{27}$ In theory and practice, there are three more models of knowledge creation and innovative creativity. Thus, the Quadruple Helix model is based on the Triple Helix model and adds the society based on culture and

\footnotetext{
${ }^{23}$ Melaas A. \& Zhang F. (2016).

$24 \mathrm{https}$ ///ec.europa.eu/info/research-and-innovation/research-area/industrial-research-andinnovation_en

${ }^{25}$ Polt W., Rammer Ch., Schartinger D., Gassler H. \& Schibany A. (2001). Benchmarking Industry-Science Relations in Europe - the Role of Framework Conditions, Science and Public Policy 28 (4), August 2001., pp. 247-258.

${ }^{26}$ Leydesdorff L. \& Strand Ø. (2013). The Swedish System of Innovation: Regional Synergies in a Knowledge-Based Economy, Journal of the American Society for Information Science and Technology.

27 OECD (2013). Triple Helix partnerstva za inovacije u Bosni i Hercegovini, Razvoj privatnog sektora - Priručnik za politike, Sarajevo, p. 17. and OECD (2005), Oslo Manual: Guidelines for collecting and interpreting innovation data, 3.issue, OECD, Paris.
} 
media and civil society as the fourth spiral. The Quadruple Helix is associated with the media, the creative industry, culture, values, lifestyle, art. The five-fold Quintuple Helix adds as a fifth spiral - the natural environment. The Quintuple Helix can be proposed as a framework for a transdisciplinary (and interdisciplinary) analysis of sustainable development and social ecology. ${ }^{28}$

Special emphasis in the process of creating innovation is placed on the phenomenon of industrial clusters, which contribute to the quality of the business environment and are an important factor in improving competitiveness. ${ }^{29}$ In literature, "industrial clusters" along with the concepts of "innovative milieus" and "self-learning regions", ${ }^{30}$ can be found under the common name of spatial innovation systems. Spatial innovation systems ${ }^{31}$ include (encompass) interconnected enterprises in specific sectors, together with relevant suppliers and the service sector, as well as a number of supporting institutions, including universities, institutes, laboratories, professional associations and agencies. This is especially important for small businesses, as they have fewer resources and opportunities for internal research of their own. Interaction with other small and micro companies facilitates access to new knowledge, which becomes a source for their innovation. ${ }^{32}$

The existing foundations of cooperation within the innovation system can be supplemented by advocating a culture of opening scientific and innovation processes, i.e. open innovation and open science. ${ }^{33}$ The new paradigm of openness will therefore not replace the existing foundations of cooperation,

28 Ješić J. (2015). Model četverostruke spirale (Quadruple Helix Model) kao osnova nacionalnog inovacionog sistema, doktorska teza, Univerzitet Edukons Fakultet poslovne ekonomije Sremska Kamenica, Novi Sad.

${ }^{29}$ Porter M. \& Stern, S. (2002). National innovative capacity. In K. Scwab, M. Porter, \& J. Sachs (Eds.), The global competitiveness report 2001-2002, 102-118. New York, NY: Oxford University Press.

${ }^{30}$ Puljiz, J. (2009). Faktori regionalnog razvoja i regionalnih nejednakosti u Republici Hrvatskoj. Doctoral dissertation, Faculty of Economics, University of Split, Split, p. 40.

${ }^{31}$ Despotović D. \& Cvetanović S. (2017). The theoretical explication of the factors of regional growth and the economic convergence (divergence) of the region, Economic Horizons, May - August 2017, Volume 19, Number 2, 111 - 125.

32 Rigg C., Coughlan P., O'Leary D. \& Coghlan D. (2021). A practice perspective on knowledge, learning and innovation - insights from an EU network of small food producers, Entrepreneurship \& Regional Development.

${ }^{33}$ Hetze P. \& Meyer M. (2018). Was bringt die Oeffnung von Wissenschaft und Innovation? Stifterverband Bildung. Wissenschaft.Innovation, Berlin and Warnke P. et al. (2016). Opening up the innovation system framework towards new actors and institutions, Fraunhofer ISI Discussion Papers - Innovation Systems and Policy Analysis, No. 49, Fraunhofer ISI, Karlsruhe. 
but will complement them, which will enable companies to more easily and quickly transform into Knowledge-Creating Companies ${ }^{34}$ and Learning Organizations. With such a business approach and strategic commitment, these companies manage to build a long-term sustainable competitive advantage, intensify cooperation with universities, and contribute to the efficiency of innovation systems, faster economic growth and competitiveness of the country.

\subsection{Indicators of economy's innovativeness}

Today, we are witnessing an explosion of research that attempts to show and compare the results of innovation in the broadest sense. ${ }^{35}$ Various organizations and researchers have developed a number of complex indicators to measure innovation at the state level. ${ }^{36}$ The most comprehensive insight into the innovation capacity and innovation performance of an individual country is provided by: 1. Global Innovation Index (GII), 2. Bloomberg Innovation Index, and 3. European Innovation Scoreboard. In addition to the above indices, which are exclusively focused on innovation, there are indices that deal with broader topics such as competitiveness, but also in part with innovation, e.g. Global Competitiveness Index (GCI). The results of examining the content $^{37}$ of the Global Competitiveness Index, the Human Development Index, the Knowledge Economy Index, the European Innovation Scoreboard indicate that these indices provide very similar information. ${ }^{38}$ Below is a brief description of the specifics of the two indices which were used in the empirical research: the Global Innovation Index (GII) and the Global Competitiveness Index (GCI).

\footnotetext{
${ }^{34}$ Vukotić S., Zakić N. \& Ćurčić N. (2017). Menadžment znanja i upravljanje inovacijama kao izvor poslovnog uspeha i konkurentske predosti preduzeća, Fourth scientific-expert gathering POLITEHNIKA 2017, pp. 436-442.

35 Adam F. (2014). Measuring National InnovationPerformance - the Innovation Union Scoreboard Revisited. Slovenia, Ljubljana: Springer.

${ }^{36}$ Gogodze J. (2016). Mechanisms and Functions within a National Innovation System Journal of Technology Management \& Innovation (C) Universidad Alberto Hurtado, Facultad de Economía y Negocios. Volume 11, Issue 4, p. 12.

${ }^{37}$ Wojciech N. (2016). Composite Indexes Economic and Social Performance: Do They Provide Valuable Information, Foundations of Management, Vol. 8, pp. 167- 174.

${ }^{38}$ Kaynak S., Altuntas S. \& Dereli T. (2017). Comparing the innovation performance of EU candidate countries: an entropy-based TOPSIS approach, Economic Research-Ekonomska Istraživanja, 30:1, 31-54.
} 
The Global Innovation Index was created in collaboration between two business schools, "Cornell - SC Johnson College of Business" and "INSEAD - The Business School for the World”, and UN's World Intellectual Property Organization - WIPO. Recognizing the key role of innovation as a driver of economic growth and prosperity, the GII includes indicators that go beyond traditional metrics of innovation. This index has linked the economic indicators that affect the country's innovation by combining them into a specific framework.

The analysis of innovation activity according to GII is composed of seven pillars of innovation grouped into two sub-indices: innovation input (III-Innovation Input Index) and innovation output (IOI-Innovation Output Index).$^{39}$ Innovation input is actually an infrastructure that enables innovation, develops an innovation culture and encourages innovative behaviour. These include: institutions, human capital and research, infrastructure, market sophistication, and business sophistication. The end result of innovation is presented in innovation output, which includes two sub-indices: knowledge and technology outputs and creative outputs. The essence of the report is reflected in the ranking of innovation capabilities and results of world economies, and in the presentation of the strengths and weaknesses of a particular country. GII enables economies to analyse their innovation performance, create appropriate innovation policies and set priorities in taking measures to strengthen innovation activity. In addition, it acts proactively, e.g. GII 2020 explores new methods of financing innovation in the post-COVID world, which are urgently needed at a time when the global economic situation is significantly aggravated by the consequences of the global pandemic.

The Global Competitiveness Index developed by the World Economic Forum (WEF) is used to rank countries based on an analysis of 12 pillars of competitiveness grouped into three sub-indices (basic factors, factors of efficiency gains and innovation and sophistication factors). Countries whose economy is based on basic factors according to the global competitiveness index are at the first level of development. Maintaining competitiveness at this level of development depends primarily on well-functioning public and private institutions (pillar 1), well-developed infrastructure (pillar 2), a stable macroeconomic environment (pillar 3) and a healthy workforce that has acquired at least primary education (pillar 4). At the second level of development are countries that achieve more efficient production processes and

${ }^{39}$ Bilas V., Bošnjak M. \& Novak I. (2019). Inovacijska izvedba zemalja članica Europske unije, Oeconomica Jadertina 1/2019., pp. 34-44. 
growing product quality. At this stage, the growth of competitiveness is influenced by higher education and vocational training (pillar 5), efficient market of goods (pillar 6), efficient labour market (pillar 7), developed financial market (pillar 8), technological readiness (pillar 9) and market size (pillar 10). Finally, at the third level are countries whose economies are based on innovation or the rapid adoption of innovative technologies. At this level, the growth of competitiveness is conditioned by factors of high business sophistication (pillar 11) and innovation (pillar 12). There are also groups of countries that are in transition between the first and second, or the second and third levels. For years, Bosnia and Herzegovina has been in the group of countries whose economies are based on efficiency, along with Albania, Macedonia, Montenegro and Serbia. Of the countries in the region, only Croatia is in the group of countries in transition from an efficiency-based economy to an innovation-based economy. ${ }^{40}$

The World Economic Forum has been measuring the competitiveness of national economies since 1979 and publishes an annual Global Competitiveness Report. The last change in the methodology was carried out during 2018, when a new method of calculating the GCI 4.0 index was introduced, and according to the same the Global Competitiveness Report for 2019 was prepared. Therefore, in the empirical part of this paper, the GII for the period 2008-2018 will be used to conduct an analysis of the impact of innovation on the competitiveness of selected countries. ${ }^{41}$

\section{Results of the empirical research}

In accordance with the set goals of the research, a comparative analysis was conducted of the Global Innovation Index (GII), the Innovation Input Index (III), the Innovation Output Index (IOI) combined, and relative to seven variables listed in section 2.3. ${ }^{42}$ Chart 1 shows the said variables for $\mathrm{BiH}$, the countries of the Western Balkans (Albania, BiH, Montenegro, Northern Macedonia and Serbia) and selected EU countries, namely: Austria, Bulgaria, Greece, Croatia, Hungary, Germany, Romania and Slovenia. Then, a regression-correlation analysis between innovation inputs and innovation outputs

\footnotetext{
${ }^{40}$ CPU-Centre for Policy and Governance, Competitiveness of Economy in $\mathrm{BiH}$ and the Region 2014-2018.

${ }^{41} \mathrm{https}$ //tcdata360.worldbank.org/indicators/gci?indicator=632\&viz=line_chart\&years=2007,2017\&i ndicators $=944$

${ }^{42}$ https://www.globalinnovationindex.org/analysis-indicator
} 
was performed, ${ }^{43}$ and a regression-correlation analysis between innovativeness and global competitiveness. The aim was to examine the relationship between R\&D expenditure and innovative activities and the competitiveness of the economy.

\subsection{Comparative analysis of innovation performance of $\mathrm{BiH}$ and selected countries}

Based on the data on the values of GII, III, IOI, as well as their basic components for Bosnia and Herzegovina, the countries of the Western Balkans and the selected EU member states, a graphic presentation no. 1 was created. It presents the relationship between the analysed innovation variables, which reflect the innovativeness of selected countries.

Figure 1. Comparative analysis of innovation variables

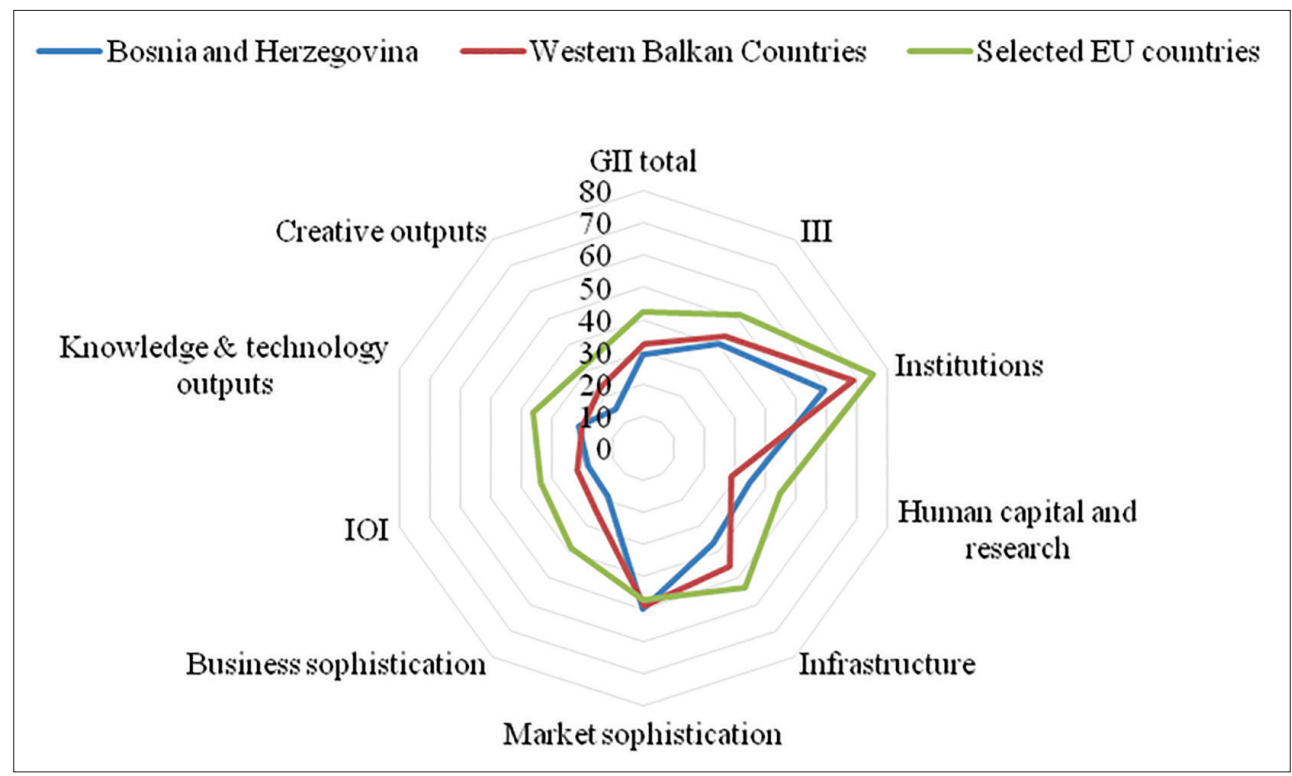

Source: Authors' calculation based on GII data for 2020

https://www.globalinnovationindex.org/analysis-indicator

The differences are clearly noticeable, i.e. lower values in innovation performance between $\mathrm{BiH}$, the Western Balkans and selected EU member states

\footnotetext{
${ }^{43}$ Cvetanović S., Despotović D., Mladenović I. \& Jovović D. (2014). The analysis of innovation in Western Balkan countries in 2012, Economic Research-Ekonomska Istraživanja, 27:1, 830-846.
} 
with the exception of the market sophistication dimension. $\mathrm{BiH}$ has high results compared to the countries of the region in the dimension of human capital and research, and is slightly better in terms of market sophistication and knowledge and technology outputs.

According to the 2020 Report of the Global Innovation Index, Bosnia and Herzegovina ranked 74th out of 131 countries, while in 2019 it was ranked 76th. The Global Innovation Index (GII) lists the following areas in 2020 as relative strengths: Human Capital, Market sophistication, Knowledge and technology outputs. Bosnia and Herzegovina achieves below-average results for its income group in four pillars: Institutions, Infrastructure, Business sophistication and Creative outputs. Even more precisely, we can list some identified particularly pronounced weaknesses in the context of our research, namely: Ease of starting a business (130th place), Innovation linkages (123rd place); Knowledge absorption (128), University/industry research collaboration (124).

\subsection{Correlative analysis of innovation and competitiveness indexes}

In addition to the comparative analysis of innovation variables, regressioncorrelation analyses were performed, namely: analysis of correlation, relationships between III (Innovation Input Index) as an independent variable and IOI (Innovation Output Index) as dependent variable for the countries of the Western Balkans and selected EU countries in 2020, and analysis of the relationship between innovation and competitiveness (GII as independent variable and GCI as dependent variable). The standard way to show the relationship between two variables is a scatter chart. In addition to the scatter chart, the results of regression-correlation linear models are presented in the figures. The representativeness of regression models is expressed by the coefficient of determination (R2), and based on that value the strength of the linear relationship, presented through regression models, is interpreted (as a share of explained variability, due to changes of independent variable, in the total variability of the dependent variable). 
Figure 2. Scatter chart and regression-correlation model for III and IOI for the countries of Western Balkans and selected EU countries
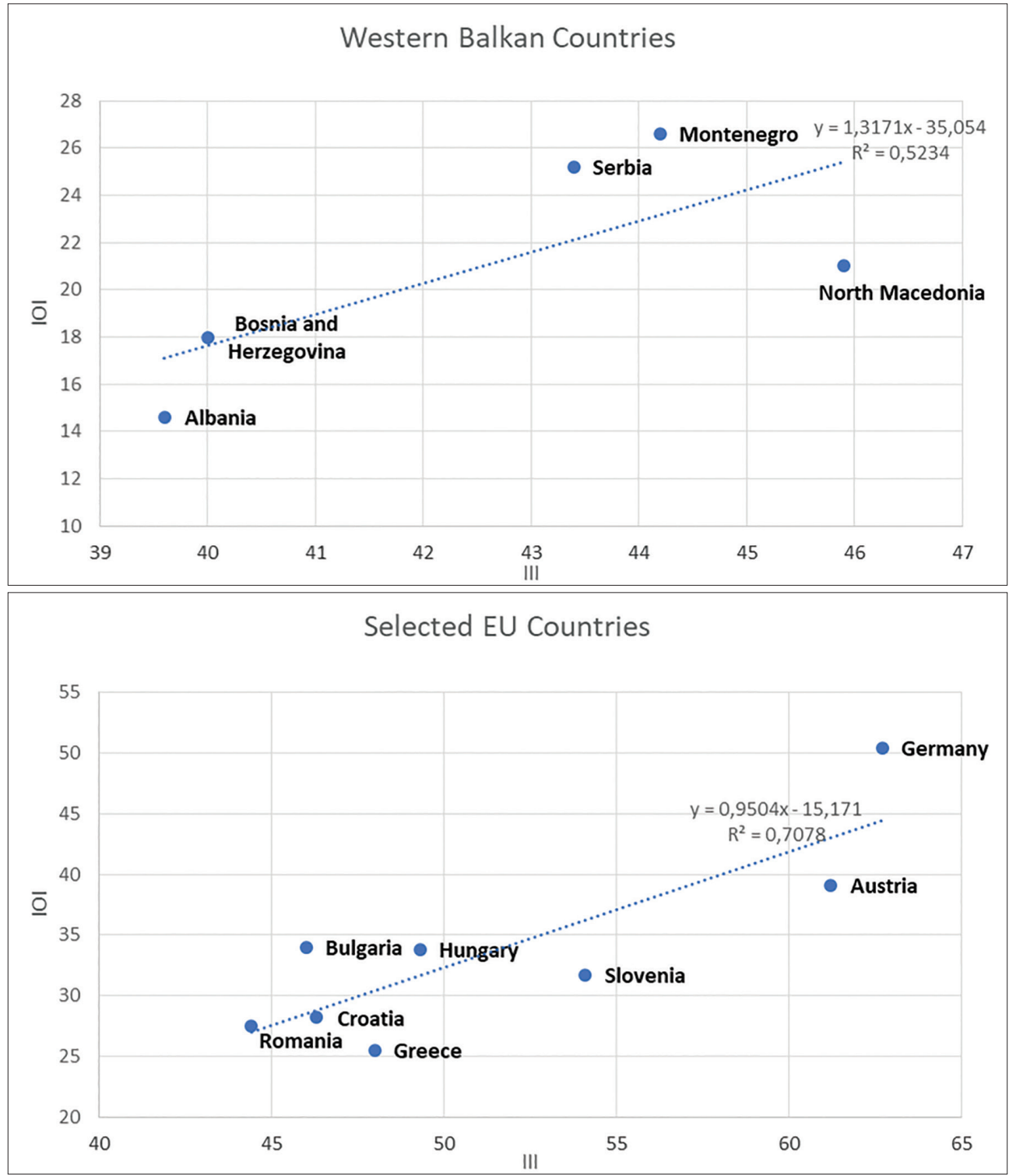

Source: Author's calculation based on GII data for 2020

https://www.globalinnovationindex.org/analysis-indicator 
Figure 2. shows two separate scatter charts between III and IOI variables for the countries of the Western Balkans and for selected EU countries. The linear model indicates a relationship of moderate strength $(52.3 \%)$ in the countries of the Western Balkans, while in selected EU countries the same model indicates a statistically more significant relationship between III and IOI, with a strength of $70.7 \%$.

In order to find the answer to which extent does innovation affect the competitiveness of selected countries, i.e. to determine the strength of the link between innovation and competitiveness, we used data, GII Reports from 2017 and GCI from 2018. We considered it unjustified to take indicators from the same year, because the soonest one can expect impact of innovative and R\&D activities on a country's competitiveness is no earlier than in the following year.

Figure 3. Scatter chart and regression-correlation model for GII and GCI for countries of the Western Balkans and selected EU countries

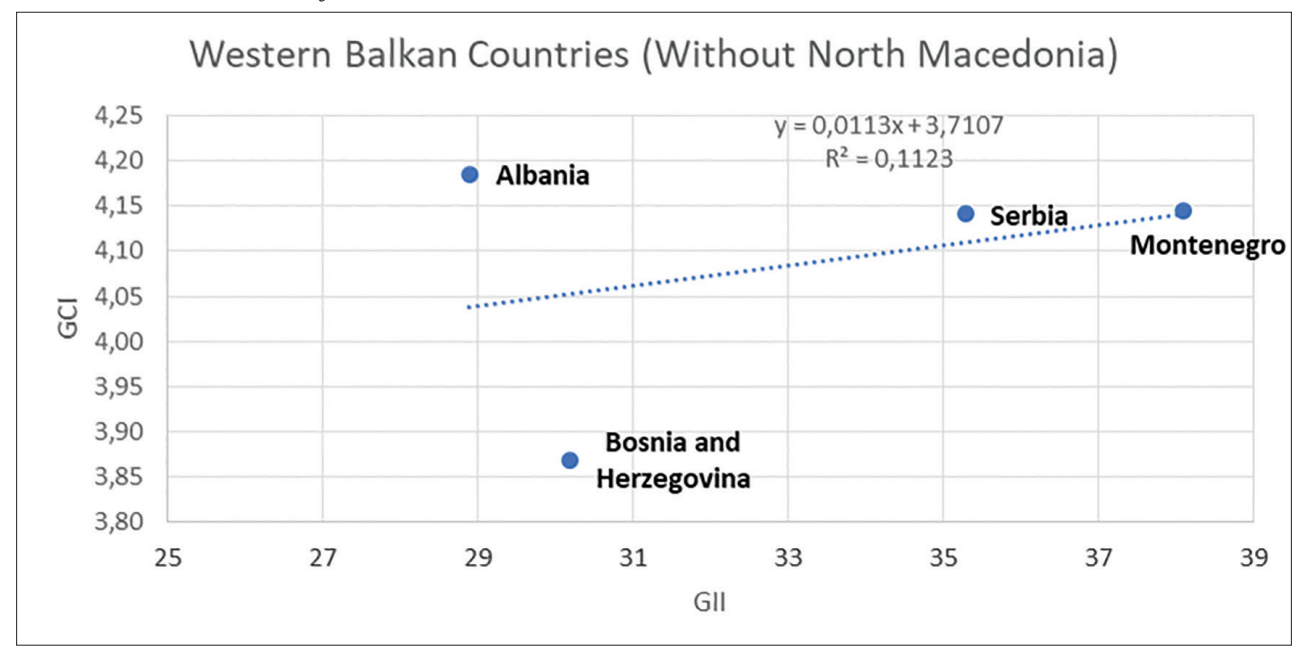




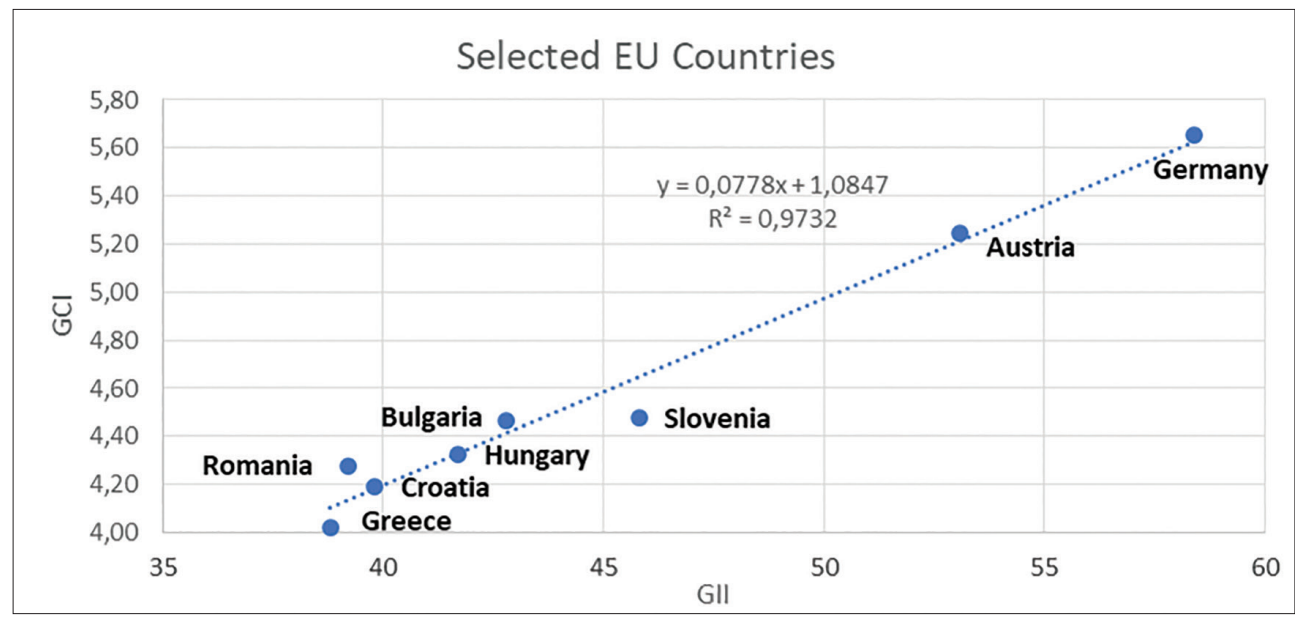

Source: Author's calculation based on GIl data for 2017 and GCl for 2018 https://www.globalinnovationindex.org/analysis-indicator and https://tcdata360.worldbank.org/indicators/gci?indicator=632\&viz=line_chart\&years=2007,2017\&indicators=944

Figure 3. presents data pairs of GII and $\mathrm{GCI}^{44}$ variables for the countries of the Western Balkans and selected EU countries. It is obvious that in selected EU countries there is a strong direct linear correlation, as well as a statistically significant impact of GII on GCI (97.3\%). On the other hand, the analysis of the relationship between GII and GCI at the level of the Western Balkans showed that there is no statistically significant impact of GII on GCI $(11.2 \%)$.

In order to find answers to the extremely weak impact of innovation variables on competitiveness in the countries of the Western Balkans, below we have analysed certain variables from the GCI for the period 2008-2018 for all selected countries, namely the 12th Pillar - Innovation, and variables related to the investment of companies into $\mathrm{R} \& \mathrm{D}$, the ability to innovate and cooperation of universities and industry in R\&D. For all these variables, selected EU countries, primarily Germany and Austria, have far higher values and better rankings. For example, the largest allocations for R\&D, shown as $\%$ of GDP in 2018, were recorded in Austria (3.17\%) and Germany (3.09\%), while between 1 and $\%$ of GDP is allocated by Slovenia (1.94 \%), Hungary $(1.55 \%)$ and Greece (1.18\%). The lowest allocations were recorded in $\mathrm{BiH}$

44 https://govdata360.worldbank.org/indicators/ha03bec65?indicator=41619\&viz=line_chart\&years= 2017,2019 
$(0.20 \%)$, followed by Montenegro $(0.37 \%)$, Romania $(0.51 \%)$, Bulgaria $(0.77 \%)$, Serbia $(0.92 \%)$ and Croatia $(0.97 \%){ }^{45}$

Nevertheless, the results of the analysis of the average annual rate of change over ten years show a different rate of movement. The fastest increase in GCI was achieved by Albania and Macedonia, on average the value of the index grew by $1.85 \%$ and $1.39 \%$, respectively, while in Greece, Croatia, Hungary and Slovenia there was a slight decrease in the index. In $\mathrm{BiH}$, the GCI is growing at an average annual rate of $0.96 \%$. A similar situation is with the 12th pillar, Innovation, where the fastest growth was achieved by Albania, $4.30 \%$, while $\mathrm{BiH}$ achieved an average annual growth of $0.81 \%$. The answer can largely be found in the structure of exports and the structure of economic activity, i.e. the representation of certain industries in employment and turnover. ${ }^{46}$

To get a more comprehensive picture of the role of companies in the functioning of the innovation system, we analysed statistics for Bosnia and Herzegovina, namely: gross domestic expenditure on research and development, the share of total gross domestic expenditure on R\&D in GDP, the number of employees in $R \& D$, the number of published research papers and the number of units engaged in R\&D for the period 2012-2019. Our focus was on indicators related to the business sector in relation to the public sector, higher education and the non-profit sector. The dominant representation of employees in $R \& D$ activities in higher education is noticeable in relation to the business sector, while their representation in the state sector is lower, and insignificant in the non-profit sector. According to the number of published research papers, higher education also dominates in relation to other observed sectors, while the number of units dealing with research and development has a smaller difference between sectors, but higher education is still ranked first. According to the research of innovative activities of companies in Bosnia and Herzegovina, which was conducted on a sample of 3,116 companies for the period 2016-2018, 35.6\% carried out at least one innovative activity, while $64.4 \%$ of companies did not carry out innovative activities. ${ }^{47}$

\footnotetext{
$45 \mathrm{https} / /$ tcdata360.worldbank.org/indicators/GB.XPD.RSDV.GD.ZS?indicator=2013\&viz=line chart\& years $=1996,2017$

${ }^{46}$ Matusiak M. \& Kleibrink A. (ed.) (2018). Supporting an Innovation Agenda for the Western Balkans: Tools and Methodologies, Publications Office of the European Union, Luxembourg, doi:10.2760/48162, JRC111430.

${ }^{47}$ Agency for Statistics of Bosnia and Herzegovina, Science, Technology and Innovation Innovation Activity of Enterprises, 2016-2018, Year IV, no. 1, Sarajevo, 30 April 2020, https://bhas.gov.ba/data/Publikacije/Saopstenja/2020/RDE_04_2016_Y2_0_BS.pdf
} 
It is particularly interesting to analyse $R \& D$ allocations, where higher education again dominates in comparison to the business sector, followed by the government and non-profit sectors. Total gross domestic expenditure on R\&D as \% of GDP is around $0.20 \%$ in the period from 2015 to 2019 . Half of that is focused on R\&D in higher education. We find similar data in the Report of the European Commission, as well as that the estimated total amount of funds that the country allocates for research is still low, at the level of $0.3 \%$ of GDP. No progress has been made in providing reliable and comprehensive research and innovation statistics. ${ }^{48}$ The budget funds of institutions that finance R\&D activities are intended mostly for the higher education sector, $91.4 \%$, followed by the state sector with $6.6 \%$ of budget funds. Other budget funds are intended for the non-profit sector, $1.6 \%$, and the business sector $0.5 \%{ }^{49}$

The following table shows all previously processed indices (GII, GCI and GCI $\operatorname{lag}^{50}$ ) and R\&D allocation indicators for Bosnia and Herzegovina in order to determine the correlation coefficient.

Table 1. Overview of GII, GCI and total gross domestic expenditure on R\&D in BiH

\begin{tabular}{lcccccc}
\hline BS & $\mathbf{2 0 1 3}$ & $\mathbf{2 0 1 4}$ & $\mathbf{2 0 1 5}$ & $\mathbf{2 0 1 6}$ & $\mathbf{2 0 1 7}$ & $\mathbf{2 0 1 8}$ \\
\hline GCl BiH & 3.93 & 4.02 & & 3.71 & 3.80 & 3.87 \\
\hline $\begin{array}{l}\text { Total gross domestic expenditure } \\
\text { on R\&D in BiH, in BAM }\end{array}$ & $86,046,335$ & $70,381,152$ & $62,494,336$ & $64,576,461$ & $62,904,269$ & $65,164,302$ \\
\hline Gll BiH & 36.2 & 32.4 & 32.3 & 29.6 & 30.2 & 31.1 \\
\hline GCl BiH lag & 4.02 & & 3.71 & 3.80 & 3.87 & \\
\hline
\end{tabular}

Source: Authors' calculation

The coefficient of linear correlation between expenditures for R\&D and GCI is 0.8673 , which means that the direct relationship between expenditures

\footnotetext{
${ }^{48}$ Bosnia and Herzegovina 2020 Report, 2020 Communication on EU Enlargement Policy, European Commission, Brussels 6 October 2020, https://ec.europa.eu/neighbourhoodenlargement/sites/near/files/bosnia_and_herzegovina_report_2020.pdf, p. 96.

${ }^{49}$ Agency for Statistics of Bosnia and Herzegovina, Science, Technology and Innovation Government Budget Appropriations or Outlays for R\&D, 2019-2020, Year VI, no. 1, Sarajevo, 21 December 2020, https://bhas.gov.ba/data/Publikacije/Saopstenja/2020/RDE_03_2019_ Y2_0_BS.pdf

${ }^{50}$ Explanation for GCI lag - the data on the amount of allocations for R\&D from one year and GCI of the following year were put in relation, e.g. expenditures from 2017 and GCI from 2018.
} 
for $\mathrm{R} \& \mathrm{D}^{51}$ and $\mathrm{GCI}$ for $\mathrm{BiH}$ in the observed period 2013-2018 has the strength of $86.73 \%$. The similarity is also noticeable in the correlation coefficient of GII with GCI, which is 0.6381 , which means that the direct connection between GII and GCI for $\mathrm{BiH}$ in the observed period has a strength of $63.81 \%$. We can conclude that both correlation coefficients are high and relatively high, which means that there is a statistically significant relationship between R\&D expenditure and GCI, and that R\&D expenditure affects the value of the competitiveness index. A slightly weaker link between GII and GCI compared to the link between R\&D and GCI indicates that the global innovation index includes more components, and a deeper analysis of the causes of these deviations would be useful and interesting.

\section{Conclusion}

Innovation and knowledge in today's dynamic and above all uncertain business environment are the key factors for achieving and maintaining the competitiveness of both companies and the national economy. The most developed countries of today have achieved their success precisely by switching from a capital-intensive to knowledge-intensive economy. One of the pillars of the knowledge economy is an effective innovation system in which companies, i.e. economic entities have a special place and role. By strengthening their R\&D activities and innovation capabilities, companies contribute to the shaping and functioning of the innovation system. However, the R\&D activity of a company depends not only on its capabilities but also on factors from the external environment such as the government's attitude towards scientific research, the relationship between scientific research institutions (universities and institutes) with businesses, the speed of technological transfer and knowledge obsolescence rate. Only by coordinating the activities of the business and academic community and the local government, i.e. by applying the Triple Helix model, synergistic effects can be achieved and higher value can be created.

The effects of innovation activity on the competitiveness of countries were investigated using the Global Innovation Index (GII) and the Global Competitiveness Index (GCI) on the example of Bosnia and Herzegovina, the Western Balkans and selected EU member states. At the same time, the analysis contributes to the assessment of the quality of their national innovation

\footnotetext{
${ }^{51}$ https://bhas.gov.ba/data/Publikacije/Saopstenja/2020/RDE_03_2019_Y2_0_BS.pdf budgetary allocations for $\mathrm{R} \& \mathrm{D}$
} 
systems. Based on the conducted analyses, it can be concluded that $\mathrm{BiH}$ and the countries of the Western Balkans achieve lower values in innovation performance, observed for the total GII, then for III (Innovation Input Index) and for IOI (Innovation Output Index). Of the seven variables of the global innovation index, the exception is the dimension of market sophistication where the countries of the Western Balkans do not lag behind (e.g. for $\mathrm{BiH}$ the value of this variable is 50.1 and for Austria it is 51.1). However, the value of GII for $\mathrm{BiH}$ is 29, compared to other observed countries only Albania has lower GII of 27.1. The highest GII values in 2020 were recorded by Germany (56.5), followed by Austria (50.1) and Slovenia (42.9).

The following conclusions are the result of an analysis of the correlation between III and IOI at the level of the Western Balkan countries and at the level of selected EU countries. The linear model determined the existence of a connection of medium strength (52.3\%) in the countries of the Western Balkans, while in the selected EU countries the same model indicates a statistically significant connection between III and IOI, with strength of $70.7 \%$. In the process of analysis of correlation between GII for 2017 and GCI for 2018, we found a strong direct linear correlation in selected EU countries, as well as a statistically significant impact of GII on GCI (97.3\%), while at the level of the Western Balkans there is no statistically significant effect of GII on GCI (11.2\%). Expenditures on R\&D (\% of GDP) and the R\&D investments of companies can be singled out as the causes of the extremely weak impact of innovation variables on the competitiveness of the Western Balkan countries. The contribution of companies to the functioning of the innovation system can also be monitored through the number of employed researchers, the number of research units and the number of published papers. These indicators are presented for Bosnia and Herzegovina, and a correlation analysis was performed between R\&D expenditures and GCI, as well as between GII and GCI, and the existence of a statistically significant relationship between R\&D investments and GCI, as well as between GII and GCI were determined.

Based on the above, we can conclude that high innovation performance cannot be expected in an economy with a low percentage of R\&D expenditures, and that low innovation represents a limiting factor of competitiveness. Therefore, companies need to develop innovation skills, and encourage R\&D activities and continuous learning. With such a proactive approach and intensive cooperation with scientific research institutions, with the support of the government, they contribute to the effective and efficient functioning 
of innovation systems, competitiveness of the economy and long-term economic and social development.

\section{References}

1. Adam F. (2014). Measuring National InnovationPerformance - the Innovation Union Scoreboard Revisited. Springer. Berlin, Heidelberg.

2. Agencija za statistiku Bosne i Hercegovine (2020). Nauka, tehnologija i inovacije - Patenti 2019, Godina VI, broj 1, Sarajevo, 15. 10. 2020, https://bhas.gov.ba/data/Publikacije/ Saopstenja/2020/RDE_02_2019_Y1_0_BS.pdf

3. Agencija za statistiku Bosne i Hercegovine (2020). Nauka, tehnologija i inovacije budžetska izdvajanja za istraživanje i razvoj, 2019.-2020., Godina VI, broj 1, Sarajevo, 21. 12. 2020., https://bhas.gov.ba/data/Publikacije/Saopstenja/2020/RDE_03_2019_ Y2_0_BS.pdf

4. Agencija za statistiku Bosne i Hercegovine (2020). Nauka, tehnologija i inovacije - Inovativne aktivnosti preduzeća, 2016-2018, Godina IV, broj 1, Sarajevo, 30. 04. 2020.

5. Bilas V., Bošnjak M. and Novak I. (2019). Inovacijska izvedba zemalja članica Europske unije. Oeconomica Jadertina 1/2019., pp. 34-44.

6. Chaminade, C. and Lundvall B. (2019). Science, Technology, and Innovation Policy:Old Patterns and New Challenges. Oxford University Press. Oxford.

7. Chuvakhina L.G., Terskaya G.A. and Buevich S.Y.(2018). Innovations as a factor of state's improved performance in the World Economic System. Revista Espacios, Vol. 39 (\# 04) Year 2018.

8. CPU-Centre for Policy and Gouvernance. Konkurentnost ekonomije u BiH i regionu 2014-2018. http://www.cpu.org.ba/media/35585/Konkurentnost-ekonomije-u-BiH-i-regionu-2014-2018.pdf (accessed on 10 June 2021)

9. Cvetanovic D., Cvetanović S. and Bogić D. (2020). Rastući značaj koncepta regionalnih inovacionih sistema za ekonomski $i$ društveni razvoj, https://konferencija.komorapirot. com/44.RASTUCI\%20ZNACAJ\%20KONCEPTA\%20REGIONALNIH\%20INOVACIONIH\%20SISTEMA\%20ZA\%20EKONOMSKI\%20I\%20DRUSTVENI\%20RAZVOJ.pdf. (accessed on 10 June 2021)

10. Cvetanović S., Despotović D., Mladenović I. and Jovović D. (2014). The analysis of innovation in Western Balkan countries in 2012. Economic Research-Ekonomska Istraživanja, 27:1, 830-846, DOI: 10.1080/1331677X.2014.974920

11. Despotović D. and Cvetanović S. (2017). The theoretical explication of the factors of regional growth and the economic convergence (divergence) of the region. Economic Horizons, May - August 2017, Volume 19, Number 2, 111 - 125.

12. Dossou Y.L. and Khvatova T.Y. (2020). Analysis of innovative activity of companies in developing countries on the example of West African countries. St. Petersburg State Polytechnical University Journal. Economics, 13 (1) (2020) 79-90. DOI: 10.18721/JE.13107

13. European Commision (2020). Science, research and Innovation Performance of the EU 2020, A fair, green and digital Europe. Publication Office of the European Union. Luxembourg. https://ec.europa.eu/info/publications/science-research-and-innovation-performance-eu-2020_en. (accessed on 10 June 2021)

14. Fatma A. (2018). Overview of the Japanese Innovation Systems vs. the American Innovation System. Journal of Global Economics, 6: 312. doi:10.4172/2375-4389.1000312 
15. Freeman, C. (1995). The "National System of Innovation" in historical perspective. Cambridge Journal of Economics, 19 (1) 5-24.

16. Gogodze J. (2016). Mechanisms and Functions within a National Innovation System. Journal of Technology Management\&Innovation, Universidad Alberto Hurtado, Facultad de Economía y Negocios. Volume 11, Issue 4, pp. 12-21.

17. Hetze P. and Meyer M. (2018). Was bringt die Oeffnung von Wissenschaft und Innovation? Stifterverband Bildung. Wissenschaft.Innovation, Berlin.

18. http://ec.europa.eu/europe2020/index_en.htm, (accessed on 10 June 2021)

19. https://tcdata360.worldbank.org/indicators/GB.XPD.RSDV.GD.ZS?indicator= $2013 \&$ viz $=$ line chart\&years $=1996,2017$, (accessed on 10 June 2021)

20. https://bhas.gov.ba/data/Publikacije/Saopstenja/2020/RDE_03_2019_Y2_0_BS.pdf

21.https://bhas.gov.ba/data/Publikacije/Saopstenja/2020/RDE_04_2016_Y2_0_BS.pdf

22. https://ec.europa.eu/info/research-and-innovation/research-area/industrial-research-andinnovation_en, (accessed on 10 June 2021)

23. https://govdata360. worldbank.org/indicators/ha03bec65? indicator $=41619 \&$ viz=line chart\&years $=2017,2019$, (accessed on 10 June 2021)

24. https://tcdata360.worldbank.org/indicators/gci?indicator $=632 \&$ viz=line_chart\&years $=2$ 007,2017\&indicators $=944$, (accessed on 10 June 2021)

25. https://www.globalinnovationindex.org/analysis-indicator, (accessed on 10 June 2021)

26. Izvještaj o Bosni i Hercegovini za 2020, Saopštenje o politici proširenja EU-a za 2020. Evropska komisija. Brisel 6.10.2020, nezvanični prevod, https://europa.ba/wp-content/ uploads/2020/10/Izvjestaj_za_BiH_za_2020_godinu.pdf (accessed on 10 June 2021)

27. Jankowska B., Matysek-Jędrych A. and Mroczek-Dąbrowska, K. (2017). Efficiency of national innovation systems: Poland and Bulgaria in the context of the Global Innovation Index. Comparative Economic Research, De Gruyter, Warsaw, Vol. 20, Iss. 3, pp. 77-94.

28. Ješić J. (2015). Model četverostruke spirale (Quadruple Helix Model) kao osnova nacionalnog inovacionog sistema. Doctoral thesis. Univerzitet Edukons Fakultet poslovne ekonomije Sremska Kamenica, Novi Sad.

29. Jovičić J. and Petković S. (2016). Inovacije kao faktor konkurentnosti privrede s osvrtom na Bosnu i Hercegovinu. Obrazovanje za preduzetništvo, 6(1), pp. 99-110.

30. Kaynak S., Altuntas S. and Dereli T. (2017). Comparing the innovation performance of EU candidate countries: an entropy-based TOPSIS approach. Economic ResearchEkonomska Istraživanja, 30:1, 31-54, DOI: 10.1080/1331677X.2016.1265895

31. Leydesdorff L. and Strand Ø. (2013). The Swedish System of Innovation: Regional Synergies in a Knowledge-Based Economy. Journal of the American Society for Information Science and Technology, DOI: 10.1002/asi.22895

32. Mandić S. and Trivunović D. (2020). Analiza konkurentnosti ekonomije Bosne i Hercegovine. Jahorina Business Forum 2020, pp. 511-520.

33. Melaas A. and Zhang F. (2016). National Innovation Systems in the United States and China A Brief Review of the Literature. The Center for International Environment\&Resource Policy, Tufs University. Medford.

34. Mosurović Ružičić M., Miletić M. and Dobrota, M. (2021). Does a National Innovation System Encourage Sustainability? Lessons from the Construction Industry in Serbia. Sustainability 2021, 13, 3591. https://doi.org/10.3390/su13073591

35. OECD (2013). Triple Helix partnerstva za inovacije u Bosni i Hercegovini. Razvoj privatnog sektora - Priručnik za politike, Sarajevo. 
36. OECD (2005). Oslo Manual: Guidelines for collecting and interpreting innovation data. 3. izdanje, OECD, Pariz.

37. Piljić J. (2018). Analiza konkurentnosti Bosne i Hercegovine i preporuke za jačanje konkurentnosti, Tranzicija/Transition. Časopis za ekonomiju i politiku tranzicije/ Journal of economic and politics of Transition, Godina XX, Vitez-Tuzla- Zagreb-BeogradBukurešt, No. 41.

38. Polt W., Rammer Ch., Schartinger D., Gassler H. and Schibany A. (2001). Benchmarking Industry-Science Relations in Europe - the Role of Framework Conditions. Science and Public Policy, 28 (4), pages 247-258, August 2001.

39. Porter M. and Stern, S. (2002). National innovative capacity. In K. Scwab, M. Porter, \& J. Sachs (Eds.), The global competitiveness report 2001-2002, 102-118. Oxford University Press. New York.

40. Puljiz J. (2009). Faktori regionalnog razvoja i regionalnih nejednakosti u Republici Hrvatskoj. Doctoral dissertation, Ekonomski fakultet, Sveučilište u Splitu. Split, Republika Hrvatska. https://www.bib.irb.hr/393855

41. Radošević S. (2002). Regional innovation systems in Central and Eastern Europe: Determinants, organizers and alignments. The Journal of Technology Transfer, 27, 87-96.

42. Rahimić Z. (2006). Izgradnja konkurentskih prednosti preduzeća kroz njegova strateška opredjeljenja. Ekonomski fakultet u Sarajevu. Sarajevo.

43. Rahimić Z. and Kožo A. (2009). Building and Development of the Knowledge Based Economy in Bosnia and Herzegovina. Journal of Interdisciplinary Management Research, Vol. V, January 2009, pp. 111-122.

44. Rigg C., Coughlan P., O’Leary D. and Coghlan D. (2021). A practice perspective on knowledge, learning and innovation - insights from an EU network of small food producers. Entrepreneurship \& Regional Development, DOI: 10.1080/08985626.2021.1877832

45. Schrempf B., Kaplan D. and Schroeder D. (2013). National, Regional, and Sectoral Systems of Innovation-An overview. Report for FP7 Project" Progress", progressproject.eu. https://www.progressproject.eu/wp-content/uploads/2013/12/Progress_D2.2_final.pdf

46. Trifković M. (2020). Harmonizacija sistema nauke u Bosni i Hercegovini. Akademija nauka i umjetnosti Bosne i Hercegovine, Centar za sistemska istraživanja, knjiga 5/1, posebna izdanja. Sarajevo.

47. Vukotić S., Zakić N. and Ćurčić N. (2017). Menadžment znanja i upravljanje inovacijama kao izvor poslovnog uspeha i konkurentske predosti preduzeća. Četvrti naučno-stručni skup POLITEHNIKA 2017, pp. 436-442.

48. Warnke P. et al. (2016). Opening up the innovation system framework towards new actors and institutions. Fraunhofer ISI Discussion Papers - Innovation Systems and Policy Analysis, No. 49, Fraunhofer ISI, Karlsruhe.

49. Wojciech N. (2016). Composite Indexes Economic and Social Performance: Do They Provide Valuable Information. Foundations of Management, Vol. 8, pp. 167- 174.

50. Yongabo P. and Göransson B (2020). Constructing the national innovation system in Rwanda: efforts and challenges. Innovation and Development, DOI:10.1080/215793 0X.2020.1846886 